\title{
STUDY OF DIFFERENT WORK MATERIALS EFFECT ON SURFACE ROUGHNESS IN ELECTROCHEMICAL MACHINING PROCESS
}

\author{
Ramandeep Singh $^{1}$, Nikhil Gandotra ${ }^{2}$, Ayyappan Solaiyappan ${ }^{3}$ \\ ${ }^{1}$ Assistant Professor, Mechanical Department, DAV University, Jalandhar Punjab, India \\ ${ }^{2}$ M.tech student, Mechanical Department, DAV University, Jalandhar, Punjab, India \\ ${ }^{3}$ Assistant Professor, Mechanical Department, GEC, Salem, Tamilnadu, India
}

\begin{abstract}
In today's manufacturing era, Electrochemical machining process provides good surface finish due to its controlled atomic dissolution of work material, involving chemical reactions during machining. To enhance the machining performance, precise selection of machining parameters, is still a demanding job in ECM process as it is very complex process involving so many unpredictable chemical reactions while machining. Due to chemical and electrical characteristics; effect on surface roughness of process also depends upon the type of material. A very rare work has been done by taking work material as input parameter for experimental study of ECM. The reaction of work material is investigated as an input parameter along with voltage and interelectrode gap on improvement in surface roughness using orthogonal Array. Work-piece material is discovered as most significant factor influencing improvement in Surface Roughness followed by Inter-electrode gap and Voltage. Effect of ECM is found to be most prominent on Brass work-piece.
\end{abstract}

Keywords: Electro chemical machining (ECM); Surface roughness (SR); Orthogonal Array; Mild steel; Brass; Aluminium; Taguchi; ANOVA.

\section{INTRODUCTION}

Electrochemical machining is a controlled atomic dissolution of work material in which material is removed from the work piece, not in a conventional manner, but by the combine action of two direct forms of energies i.e. electrical and chemical. ECM process relies on the principle of electrolysis [3]. In electrolysis, two electrodes immersed into a liquid solution also called electrolytic solution, in order to deplete metal from anode and plated on cathode, when the electric current is passed between them [2]. Though, the principle of electrolysis was in use for a long time in a process called electroplating. But with certain modifications, ECM is often characterized as "reverse electroplating", with difference of no deposition of work material on cathode.

In today's manufacturing era, machining quality relies on surface finish of the machined work piece to a great extent. ECM contributed a lot to achieve good surface finish while machining. To enhance the machining performance, precise selection of machining parameters, is still a demanding job in ECM process as it is very complex process involving so many unpredictable chemical reactions while machining. Various investigations have been carried out for improving the surface roughness process characteristic of ECM process by numerous researchers. Neto, J., et al. [1] took material removal rate (MRR), surface roughness (SR) and over-cut as response parameter for studying process variables in electrochemical machining (ECM) of Valve-Steel. Surface roughness decreases with increase in tool feed rate. Ganesan, G., et al. [5] used non-dominated sorting genetic
algorithm-II (NSGA-II) to optimize ECM process. Production rate was increased considerably by reducing machining time Chakradhar, D., and Gopal, A., [4] found tool feed rate as most influencing machining parameter by performing ANOVA in investigation and optimization of EN-31 steel, using grey relation analysis. Acharya, B.R., et al. [6] adopted Response Surface Methodology to investigate the effect of four machining parameters i.e. electric current, voltage, electrolyte flow rate and interelectrode gap on MRR and SR. Surface roughness was influenced greatly by current. Goswami, R., et al. [8] reported the ECM of Mild Steel and Aluminium by using Taguchi approach to analyze and predict optimal process input characteristics for surface roughness and material removal rate. For both materials, current was most significant machining parameter for SR. Bisht, B., et al. [7] used mild steel and aluminium as work material in ECM process to optimize the machining performance. It was concluded that aluminium alloy had good surface finish as compared to mild steel. Das, M.K., et al. [9] applied Artificial Bee Colony Algorithm for investigating electrochemical machining of EN31 steel to optimize MRR and SR. Scanning electron microscopy (SEM) images were used to study surface characteristics. Surface roughness was greatly influenced by electrolyte concentration. Sathiyamoorthy, V., and Sekar, T., [11] used $\mathrm{NaCl}$ aqueous solution in electrochemical machining of die steel and three electrolyte jet patterns namely straight jet in circular, inclined jet in circular and straight jet in spiral to analyze the influence of electrolyte distribution on material removal rate (MRR) and surface roughness (SR). Straight jet in spiral pattern performed significantly in improving the 
performance of ECM. Habib, S.S., [10] used Taguchi approach for optimization of ECM response characteristics viz. MRR and SR by taking voltage, tool feed rate, electrolyte concentration and current as machining parameters. Voltage influence MRR and current influence SR significantly. Rao, S.R., and Padmanabhan, G., [12] done electrochemical machining process investigation by using utility based taguchi method. Voltage, electrolyte concentration, electrode feed rate and percentage of reinforcement were machining parameters influencing MRR, SR and ROC. From ANOVA, tool feed rate was most significant machining parameter.

In the past, various researchers have attempted to study and optimize ECM process by taking process input parameters such as electric current, voltage, tool feed rate, electrolyte concentration, electrolyte flow rate, inter-electrode gap etc. and analysing their effect on response parameters viz. material removal rate, surface roughness, radial overcut etc., which decide the cutting performance. A very rare work has been done by taking work material as input parameter for experimental study of ECM, as performance of process also be influenced by type of work material due to its chemical and electrical characteristics. Inspite of other important input parameters, work material is one of the important parameter, which affects SR. As ECM is an atomic dissolution of work material involving chemical reactions during machining, so chemical characteristics of work material do affect the response parameters.
In the current research work, an effort has been made to study the effect of input parameters on Percentage Improvement in $\mathrm{R}_{\mathrm{a}}\left(\% \Delta \mathrm{R}_{\mathrm{a}}\right)$ by selecting work material as an input parameter along with voltage and inter-electrode gap as another two parameters and optimize these input parameters to improve $\% \Delta \mathrm{R}_{\mathrm{a}}$, using hexagonal shaped copper electrode and Taguchi method. Three different materials i.e. Mild Steel, Brass and Aluminium are taken for experiments which are widely used in industries.

\section{EXPERIMENTAL DETAILS}

\subsection{Experimental Set-Up}

Electrochemical machining apparatus of Metatech-Industry, Pune was used for conducting experiments as shown in figure-1. The ECM apparatus comprises of machining unit, control panel, electrolyte circulation tank. Machining unit is a tough structure, accompanied with many precise components which help in machining. It comprises of a job holding vice and stepper motor-electrolyte supply arrangement where tool is fixed, which helps in the movement of tool and electrolyte flow. Control panel act as input device which can vary the parameters like current, voltage and feed rate. Control panel supplies power to the machining unit. Its main function is to run and control the machining process. The electrolyte circulation tank is fitted with pump which supplies the electrolyte to machining unit; a pressure gauge for determining the electrolyte pressure and a flow control valve for deciding the amount of flow.

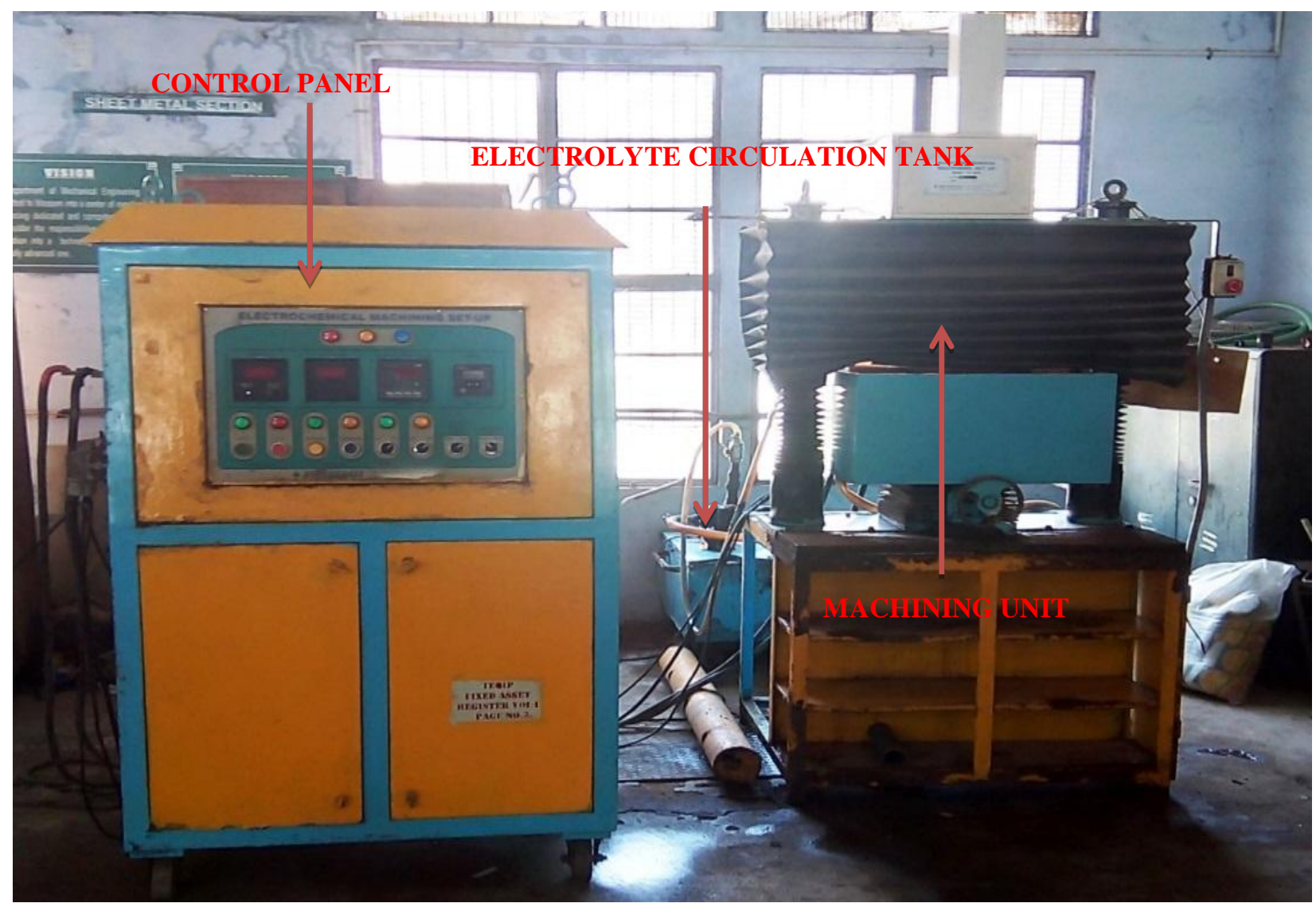

Fig-1: ECM Set-up 


\subsection{Selection of Work-Piece Material}

In the present research work, three different work materials were chosen for experiments. The materials used were Mild Steel, Brass and Aluminium. These are the commonly used materials in industries for the fabrication of different components and having very wide applications. Workpieces, equal number of each material, circular in shape were taken for experiments having dimension of $30 \mathrm{~mm}$ in diameter and $20 \mathrm{~mm}$ in thickness, as shown in figure-2. Each work-piece was fabricated with the help of turning operation. The chemical composition of work-piece sample of mild steel, brass and aluminium used for present investigation is as in table-1(a), 1(b) and 1(c).

Table-1(a): Chemical Composition of Mild Steel Work-piece

\begin{tabular}{|l|l|l|l|l|l|}
\hline Element & $\mathrm{C}$ & $\mathrm{Si}$ & $\mathrm{Mn}$ & $\mathrm{P}$ & $\mathrm{S}$ \\
\hline Weight \% & 0.28 & 0.270 & 0.587 & 0.0285 & 0.0210 \\
\hline
\end{tabular}

Table-1(b): Chemical Composition of Brass Work-piece

\begin{tabular}{|l|l|l|l|l|l|l|l|l|l|l|}
\hline Element & $\mathrm{Cu}$ & $\mathrm{Zn}$ & $\mathrm{PB}$ & $\mathrm{Sn}$ & $\mathrm{Mn}$ & $\mathrm{Fe}$ & $\mathrm{Ni}$ & $\mathrm{Si}$ & $\mathrm{Al}$ & $\mathrm{Sb}$ \\
\hline Weight \% & 56.1 & 39.3 & 3.23 & 0.37 & 0.03 & 0.29 & 0.28 & 0.03 & 0.10 & 0.01 \\
\hline
\end{tabular}

Table-1(c): Chemical Composition of Aluminium Work-piece

\begin{tabular}{|l|l|l|l|l|l|l|l|l|l|}
\hline Element & $\mathrm{Al}$ & $\mathrm{Si}$ & $\mathrm{Fe}$ & $\mathrm{Cu}$ & $\mathrm{Mn}$ & $\mathrm{Mg}$ & $\mathrm{Zn}$ & $\mathrm{Cr}$ & $\mathrm{Ti}$ \\
\hline Weight \% & 98.3 & 0.494 & 0.432 & 0.039 & 0.058 & 0.464 & 0.053 & 0.009 & 0.015 \\
\hline
\end{tabular}

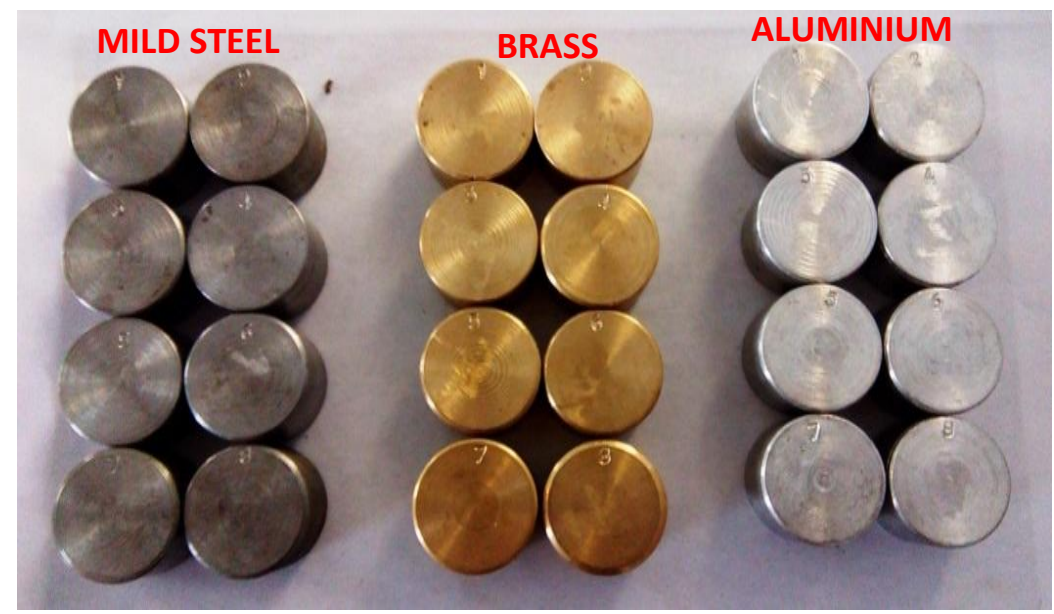

Fig-2: Pool of Work-pieces; extreme left- Mild steel, middle- Brass and extreme right- Aluminium

\subsection{Tool and Electrolyte}

Copper as tool was chosen for present investigation as it has very high thermal and electrical conductivity. The machining area of tool is hexagonal in shape; with head of $3 \mathrm{~mm}$ thickness and $2 \mathrm{~mm}$ hole at Centre of hexagonal shaped end of rod for the flow of electrolyte during machining (refer Figure-3). For my present investigation, $\mathrm{NaCl}$ is used as electrolyte and mineral water to make electrolytic solution, since $\mathrm{NaCl}$ is a non-passive electrolyte and do not affect the work-piece surface. Electrolyte concentration has been kept constant throughout at $150 \mathrm{~g}$ of $\mathrm{NaCl}$ to 1 liter of mineral water. The various process variables and their limits are specified as in table-2.

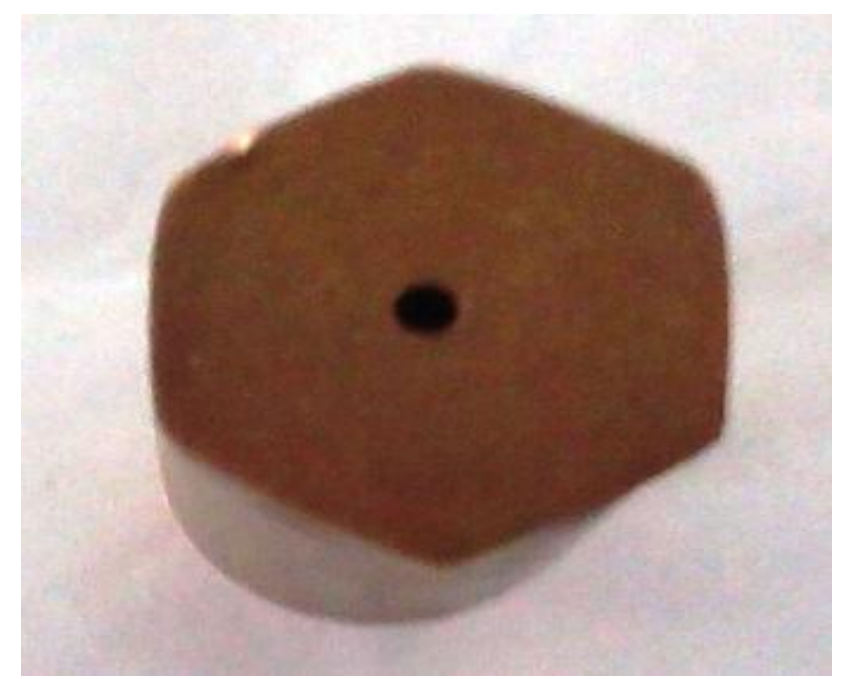

Fig-3: Machining area of copper tool 
Table-2: Process Variables and their Limits

\begin{tabular}{|l|l|l|l|}
\hline V.NO & VARIABLES & UNIT & LIMITS \\
\hline 1 & voltage & V & $10-18$ \\
\hline 2 & current & A & $0-280$ \\
\hline 3 & Power supply & Nil & DC-Continuous \\
\hline 4 & Work-Piece Material & Nil & Mild Steel, Brass and Aluminium \\
\hline 5 & Tool Material & Nil & Copper \\
\hline 6 & Tool-Electrode Condition & Nil & Non-Rotating \\
\hline 7 & No. of Holes in Tool & Nil & 1 \\
\hline 8 & Tool Feed Rate & $\mathrm{mm} / \mathrm{min}$ & 0.1 \\
\hline 9 & Inter-Electrode Gap & $\mathrm{mm}$ & $0.2-0.6$ \\
\hline 10 & Electrolyte Type & $\mathrm{Nil}$ & NaCl aqua solution \\
\hline 11 & Electrolyte Concentration & $\mathrm{g} / \mathrm{L}$ & 150 \\
\hline 12 & Electrolyte Flow Rate & $\mathrm{L} / \mathrm{min}$ & 9 \\
\hline 13 & Electrolyte Temperature & ${ }^{0} \mathrm{C}$ & 28 \\
\hline 14 & Electrolyte Pressure & $\mathrm{Kg} / \mathrm{cm}^{2}$ & 27 \\
\hline 15 & Machining Time & $\mathrm{Min}$ & 10 \\
\hline
\end{tabular}

\section{SCHEME OF EXPERIMENT}

For the present experimental work, Taguchi $\mathrm{L}_{9}$ orthogonal array having eight degree of freedom was used. From eight degree of freedom, six degree of freedom was assigned to three parameters; each parameter has two degree of freedom and two degree of freedom was assigned to the error. According to Taguchi's methodology, the total DOF required for the experiment must be less than or equal to selected OA. Nine experiments were conducted according to selected $\mathrm{L}_{9} \mathrm{OA}$. Three process parameters viz. work-piece material, voltage and inter-electrode gap (IEG) were taken as machining parameters. The degree of influence of the machining parameters in ECM was determined by taking, three factors, each at three levels, with equal spacing of the cutting parameters, as shown in Table-3. The different levels of machining parameters were allocated in standard $\mathrm{L}_{9} \mathrm{OA}$ by means of linear graphs is given in Table- 4 .

Table-3: Machining Parameters and their Stages

\begin{tabular}{|l|l|l|l|l|l|}
\hline \multirow{2}{*}{ MACHINING PARAMETER } & \multirow{2}{*}{ REPRESENTATION } & \multirow{2}{*}{ UNIT } & \multicolumn{2}{|l|}{ STAGES } \\
\cline { 4 - 6 } & & & STAGE-1 & STAGE-2 & STAGE-3 \\
\hline Work-Piece Material & $\mathrm{W}$ & - & $\begin{array}{l}\text { Mild Steel } \\
(\mathrm{M})\end{array}$ & $\begin{array}{l}\text { Brass } \\
(\mathrm{B})\end{array}$ & $\begin{array}{l}\text { Aluminium } \\
(\mathrm{A})\end{array}$ \\
\hline Voltage & $\mathrm{V}$ & Volts & 10 & 14 & 18 \\
\hline Inter-Electrode Gap & $\mathrm{G}$ & $\mathrm{mm}$ & 0.2 & 0.4 & 0.6 \\
\hline
\end{tabular}

Table-4: Assignment of Parameters in $\mathrm{L}_{9}$ Orthogonal Array with Response

\begin{tabular}{|c|c|c|c|c|c|c|c|c|}
\hline \multirow[t]{3}{*}{$\begin{array}{l}\text { EXP } \\
\text { NO. }\end{array}$} & \multirow[t]{3}{*}{$\begin{array}{l}\text { ORDER } \\
\text { OF RUN }\end{array}$} & \multicolumn{3}{|c|}{$\begin{array}{l}\text { MACHINING } \\
\text { PARAMETERS TRIAL } \\
\text { CONDITIONS }\end{array}$} & \multicolumn{3}{|c|}{$\begin{array}{l}\text { RESPONSE \% } \Delta \mathbf{R}_{\mathrm{a}} \\
\text { (RAW DATA) }\end{array}$} & \multirow[t]{3}{*}{ SNR (db) } \\
\hline & & W & $\mathbf{V}$ & $\mathbf{G}$ & $\mathbf{R}_{1}$ & $\mathbf{R}_{2}$ & $\mathbf{R}_{3}$ & \\
\hline & & 1 & 2 & 3 & & & & \\
\hline 1 & 1 & $1(\mathrm{M})$ & 1 (10) & $1(0.2)$ & 22.04 & 28.01 & 25.03 & 27.84 \\
\hline 2 & 4 & $1(\mathrm{M})$ & $2(14)$ & $2(0.4)$ & 37.50 & 32.54 & 35.02 & 30.84 \\
\hline 3 & 7 & $1(\mathrm{M})$ & $3(18)$ & $3(0.6)$ & 54.04 & 66.84 & 60.44 & 35.53 \\
\hline 4 & 2 & 2 (B) & $1(10)$ & $2(0.4)$ & 47.29 & 59.9 & 53.60 & 34.46 \\
\hline 5 & 5 & 2 (B) & $2(14)$ & $3(0.6)$ & 62.43 & 67.43 & 64.93 & 36.24 \\
\hline 6 & 8 & 2 (B) & $3(18)$ & $1(0.2)$ & 67.49 & 62.18 & 64.84 & 36.22 \\
\hline 7 & 3 & $3(\mathrm{~A})$ & $1(10)$ & $3(0.6)$ & 70.31 & 62.94 & 66.63 & 36.45 \\
\hline 8 & 6 & $3(\mathrm{~A})$ & $2(14)$ & $1(0.2)$ & 29.47 & 78.75 & 54.11 & 32.59 \\
\hline 9 & 9 & $3(\mathrm{~A})$ & $3(18)$ & $2(0.4)$ & 68.15 & 73.32 & 70.74 & 36.98 \\
\hline TOTAL & & & & & 458.72 & 531.91 & 495.32 & \\
\hline
\end{tabular}




\section{RESULTS AND ANALYSIS}

From experimental data, the mean values of response parameter and Signal-to-Noise Ratio $(\mathrm{dB})$ for each machining parameter at level one, level two and level three $(\mathrm{L} 1, \mathrm{~L} 2, \mathrm{~L} 3)$ are calculated as per in table-5. The main effects of machining parameters both for raw data and SNR data are plotted in figure- $4(a, b$ and $c)$. The significance and optimal conditions of machining parameters for mean response parameter are recognized by analyzing response curves and the ANOVA Tables.

Table-5: Mean values \& main effects of Percentage improvement in surface roughness $\left(\Delta R_{a}\right)$

\begin{tabular}{|c|c|c|c|c|c|c|c|}
\hline $\begin{array}{l}\text { Machining } \\
\text { Parameter }\end{array}$ & Stage & \multicolumn{2}{|c|}{ Work-piece Material } & \multicolumn{2}{|c|}{ Voltage } & \multicolumn{2}{|l|}{ IEG } \\
\hline \multicolumn{2}{|l|}{$\begin{array}{l}\text { Type of Data } \\
\text { Levels }\end{array}$} & $\begin{array}{l}\text { Raw } \\
\text { Data }\end{array}$ & $\begin{array}{l}\text { SNR } \\
(\mathrm{dB})\end{array}$ & $\begin{array}{l}\text { Raw } \\
\text { Data }\end{array}$ & $\begin{array}{l}\text { SNR } \\
(\mathrm{dB})\end{array}$ & $\begin{array}{l}\text { Raw } \\
\text { Data }\end{array}$ & SNR (dB) \\
\hline \multirow{3}{*}{$\begin{array}{l}\text { Mean } \\
\text { (SR) }\end{array}$} & $\mathrm{S}_{1}$ & 40.16 & 31.41 & 48.42 & 32.92 & 47.99 & 32.22 \\
\hline & $\mathrm{S}_{2}$ & 61.12 & 35.64 & 51.35 & 33.22 & 53.12 & 34.10 \\
\hline & $\mathrm{S}_{3}$ & 63.82 & 35.34 & 65.34 & 36.24 & 63.10 & 36.07 \\
\hline \multirow{2}{*}{$\begin{array}{l}\text { Main } \\
\text { (SR) }\end{array}$} & $\mathrm{S}_{2}-\mathrm{S}_{1}$ & 20.96 & 4.24 & 2.94 & 0.31 & 5.13 & 1.88 \\
\hline & $\mathrm{S}_{3}-\mathrm{S}_{2}$ & 2.71 & $\begin{array}{c}-0.30 \\
\end{array}$ & 13.98 & 3.02 & 10.88 & 1.98 \\
\hline \multicolumn{2}{|c|}{$\begin{array}{l}\text { Difference }\left\{\left(\mathrm{S}_{3}-\mathrm{S}_{2}\right)-\left(\mathrm{S}_{2^{-}}\right.\right. \\
\left.\left.\mathrm{S}_{1}\right)\right\}\end{array}$} & -18.26 & -4.54 & 11.05 & 2.72 & 5.76 & 0.10 \\
\hline
\end{tabular}
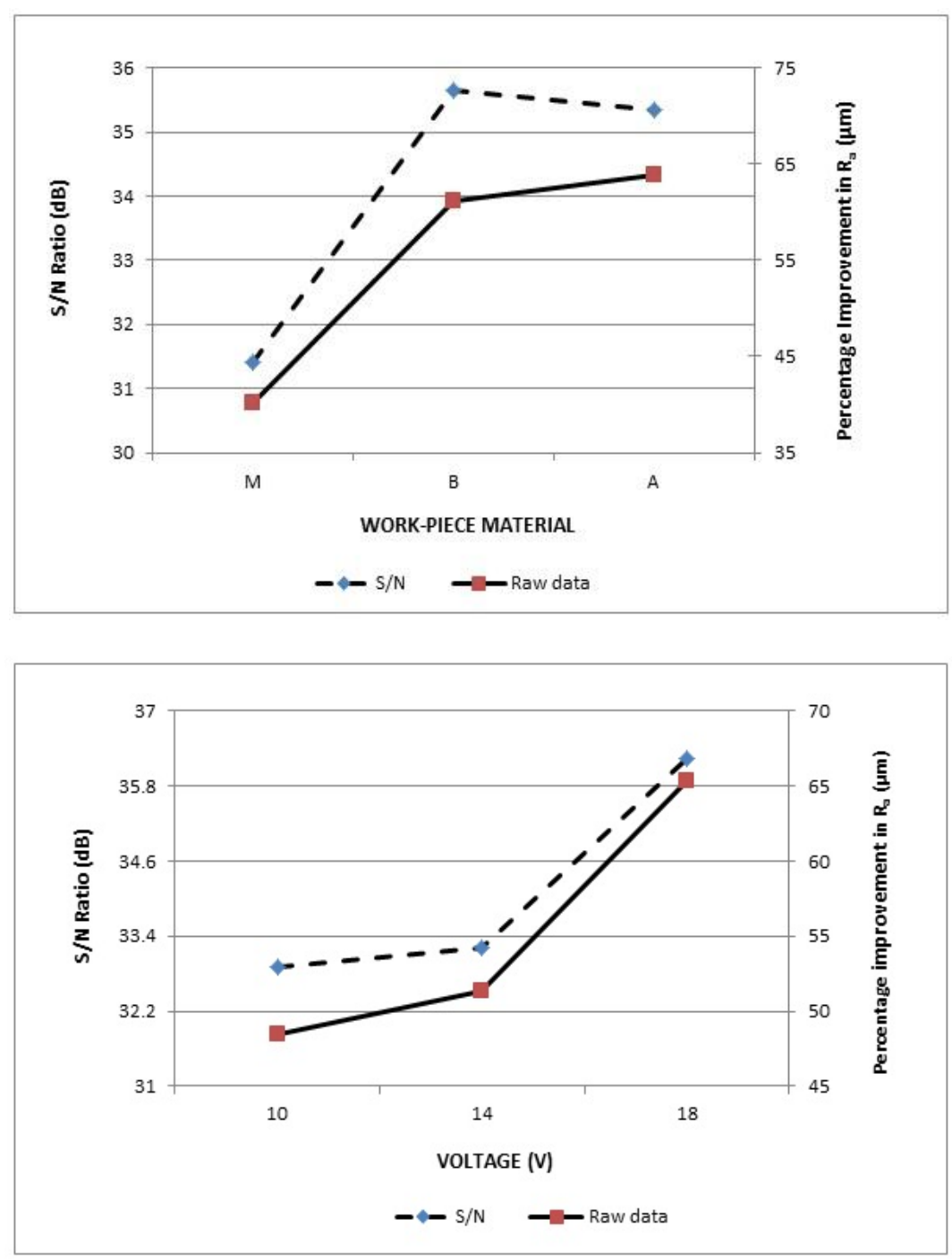


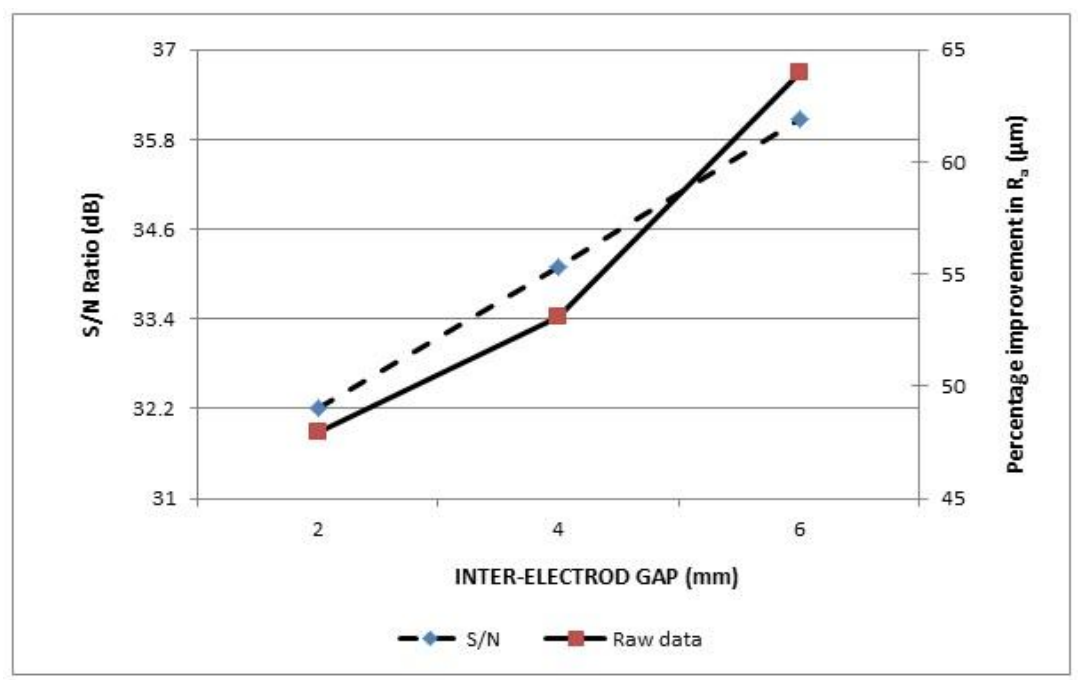

Fig- 4(a) Influence of Work-piece Material; (b) Effect of Voltage and (c) Effect of IEG on S/N ratio and percentage improvement in Surface Roughness

The effect of Work-piece Material on Percentage Improvement in Surface Roughness and Signal-to-Noise Ratio is clearly visible in Figure-4(a). Figure shows that the percentage improvement in $\mathrm{R}_{\mathrm{a}}$ is highest when brass is used as work-piece and lowest in case of mild steel. Percentage improvement in $R_{a}$ is almost same in case of brass and aluminium. This is due to different characteristics of different materials like Crystallographic irregularities, such as dislocation. An uneven distribution of current density is produced due to different composition of alloy, which leaves the microscopic peaks and valleys that form poor surface finish. More fine grained as well as homogenous structures produce a better surface quality. It also depends on the machining conditions and electrolyte selected for machining.

Figure-4(b) represents the influence of voltage on Signal-tonoise ratio (SNR) and Percentage improvement in $R_{a}$. Percentage Improvement in $\mathrm{R}_{\mathrm{a}}$ increases directly as the voltage is changed from $10 \mathrm{~V}$ to $18 \mathrm{~V}$. Highest percentage improvement in $R_{a}$ is obtained at $18 \mathrm{~V}$. The lowest percentage improvement in $R_{a}$ is observed when $10 \mathrm{~V}$ voltage is used. There is less increase in surface finish when voltage changes from $10 \mathrm{~V}$ to $14 \mathrm{~V}$ as when voltage changes from $14 \mathrm{~V}$ to $18 \mathrm{~V}$. This is due to reason that surface finish increases with increase in current and current increases when voltage is increased. When the applied voltage is low, current in the IEG is lower which leads to uneven dissolution of material resulting higher surface roughness and vice-versa.

One more parameter that affects the percentage improvement in $R_{a}$ is Inter-Electrode Gap. Figure-4(c) shows the variation of percentage improvement in $R_{a}$ with respect to various values of IEG. The Figure show that the percentage improvement in $\mathrm{R}_{\mathrm{a}}$ increases directly and linearly when IEG changes from $0.2 \mathrm{~mm}$ to $0.6 \mathrm{~mm}$. Lower value of percentage improvement in $R_{a}$ is observed at $0.2 \mathrm{~mm}$ IEG and highest value of percentage improvement in $R_{a}$ is observed at $0.6 \mathrm{~mm}$ IEG. This is due to reason that the electrolyte used was concentrated $\mathrm{NaCl}$. Salts crystallize out of the solution at higher concentrations which increase the MR but decrease the surface finish. So, surface finish will be better at high IEG and high voltage using concentrated electrolyte.

Analysis of Variance (ANOVA) was executed on experimental data to find significance of the machining parameters towards the Percentage Improvement in Surface Roughness. The Pooled ANOVA of raw data and the SNR data for percentage improvement in $\mathrm{R}_{\mathrm{a}}$ are given in Tables- 6 and 7.

Table-6: Pooled ANOVA of Raw Data for Percentage Improvement in Surface Roughness

\begin{tabular}{|l|l|l|l|l|l|}
\hline SOURCE & SS & DOF & V & F- RATIO & P\% \\
\hline Work-piece Material & 33.50 & 2 & 16.75 & 32.85 & 43.45 \\
\hline Voltage & 20.30 & 2 & 10.15 & 19.91 & 26.33 \\
\hline IEG & 22.28 & 2 & 11.14 & 21.85 & 28.90 \\
\hline Error & 1.02 & 20 & 0.51 & & 1.32 \\
\hline Total (T) & 77.09 & 26 & -- & & 100 \\
\hline $\begin{array}{l}\text { Significance at 95\% confidence level, } \text { F }_{\text {critical }}=3.55 \\
\text { SS- Sum of Squares, DOF- Degree of Freedom, V- Variance }\end{array}$ & \\
\hline
\end{tabular}


Table-7: Pooled ANOVA of S/N Ratio Data for Percentage Improvement in Surface Roughness

\begin{tabular}{|l|l|l|l|l|l|}
\hline SOURCE & SS & DOF & V & F- RATIO & P\% \\
\hline Work-piece Material & 3019.30 & 2 & 1509.65 & 20.08 & 41.95 \\
\hline Voltage & 1471.53 & 2 & 735.77 & 9.79 & 20.45 \\
\hline IEG & 1202.88 & 2 & 601.44 & 8.00 & 16.71 \\
\hline Error & 1503.55 & 2 & 75.18 & & 20.89 \\
\hline Total (T) & 7197.27 & 8 & -- & & 100 \\
\hline $\begin{array}{l}\text { Significance at 95\% confidence level, } \text { F }_{\text {critical }}=3.55 \\
\text { SS- Sum of Squares, DOF- Degree of Freedom, V- Variance }\end{array}$ \\
\hline
\end{tabular}

From ANOVA tables, the mean and variation in percentage improvement in surface roughness values were considerably affected by work-piece material, voltage and IEG. The percentage influence of work-piece material is highest $(43.45 \%)$ for improvement in surface roughness followed by the IEG $(28.90 \%)$, and voltage $(26.33 \%)$. Percentage improvement in surface roughness is considered as "higher the better" type of quality characteristic. Therefore, higher values of machining parameters are considered to be optimal.

The S/N ratio analysis (refer Table-5 and Figure-4) suggests that Second level of material of work-piece (Brass) and Third level of voltage $(18 \mathrm{~V})$ and IEG $(0.6 \mathrm{~mm})$ are the optimum levels of parameters for maximum percentage improvement in $\mathrm{R}_{\mathrm{a}}$ (i.e. Least Surface Roughness).

\section{ASSESSMENT OF OPTIMAL VALUE OF RESPONSE PARAMETER}

The effect of the significant machining parameters helps in assessment of optimal value of response parameter within confidence interval. The confirmation experimentations give the mean value of response parameter, which must lie within the $95 \%$ confidence interval of confirmation experiment and mean value of quality characteristic obtained from the confirmation experiments may or may not lie within $95 \%$ confidence interval of population.

The optimal value of $\Delta \mathrm{R}_{\mathrm{a}}$ is estimated as:

$$
\Delta \mathbf{R}_{\mathrm{a}}=\overline{W_{2}}+\overline{V_{3}}+\overline{G_{3}}-2 \bar{T}
$$

$\overline{\mathrm{T}}=$ overall mean of response $=55.04($ Table -4$)$

$\overline{W_{2}}=$ Mean value of $\mathrm{R}_{\mathrm{a}}$ at the 2 nd level of Work-piece Material $=$

$61.12($ Table-5)

$\overline{V_{3}}=$ Mean value of $\mathrm{R}_{\mathrm{a}}$ at the 3 rd level of Voltage $=65.34$

(Table-5)

$\overline{G_{3}}=$ Mean value of $\mathrm{R}_{\mathrm{a}}$ at the 3 rd level of $\mathrm{IEG}=63.10$

(Table-5)

Substituting these values in equation $1, \Delta \mathbf{R}_{\mathbf{a}}=79.48$
The confidence interval of confirmation experiments $\left(\mathrm{CI}_{\mathrm{CE}}\right)$ and of population $\left(\mathrm{CI}_{\mathrm{POP}}\right)$ is calculated by using the following equations:

$$
\begin{aligned}
& \mathrm{CI}_{\mathrm{CE}}=\sqrt{\mathrm{F}_{\alpha}\left(1, \mathrm{f}_{\mathrm{e}}\right) \mathrm{V}_{\mathrm{e}}\left[\frac{1}{\mathrm{n}_{\mathrm{eff}}}+\frac{1}{\mathrm{R}}\right]} \\
& \mathrm{CI}_{\mathrm{POP}}=\sqrt{\frac{\mathrm{F}_{\alpha}\left(1, \mathrm{f}_{\mathrm{e}}\right) \mathrm{V}_{\mathrm{e}}}{\mathrm{n}_{\mathrm{eff}}}}
\end{aligned}
$$

Where,

$F_{\alpha}\left(1, f_{e}\right)=$ The F-ratio at the confidence level of $(1-\alpha)$ against DOF 1 and error degree of freedom $f_{e}=4.35$ (Tabulated $\mathrm{F}$ value)

$\mathrm{f}_{\mathrm{e}}=$ Error DOF $=20$ (Table-6)

$\mathrm{N}=$ Total number of outcome $=27$ (conduct $=9$, replication =3)

$\mathrm{R}=$ Sample size for confirmation experiments $=3$

$\mathrm{V}_{\mathrm{e}}=$ Variance Error $=0.51($ Table-6)

$n_{\text {eff }}=\frac{\mathrm{N}}{1+[\text { DOF associated in the predicted mean response }]}=3.87$

So, $\quad \mathrm{CI}_{\mathrm{CE}}= \pm 1.146$

And $\quad \mathrm{CI}_{\mathrm{POP}}= \pm 0.758$

The $95 \%$ confidence interval of predicted optimal range is:

Mean $\mathrm{R}_{\mathrm{a}}-\mathrm{CI}_{\mathrm{CE}}\left\langle\Delta \mathrm{R}_{\mathrm{a}}\right\rangle$ Mean $\mathrm{R}_{\mathrm{a}}+\mathrm{CI}_{\mathrm{CE}}$ $78.344<\Delta \mathrm{R}_{\mathrm{a}}>80.626$

The $95 \%$ confidence interval of the predicted mean is:

Mean $\mathrm{R}_{\mathrm{a}}-\mathrm{CI}_{\text {POP }}<\Delta \mathrm{R}_{\mathrm{a}}>$ Mean $\mathrm{R}_{\mathrm{a}}+\mathrm{CI}_{\text {POP }}$ $78.722<\Delta \mathrm{R}_{\mathrm{a}}>80.238$

\section{CONFIRMATION EXPERIMENT}

Three confirmation experiments were performed, to authenticate the results acquired, for response parameter i.e. percentage improvement in $\mathrm{R}_{\mathrm{a}}$ at the optimal levels of Work-piece Material at Second level $\left(\mathrm{W}_{2}\right)$, Voltage at level Three $\left(V_{3}\right)$, and IEG which is also at Third level $\left(G_{3}\right)$. The confirmation result is given in table-8. The experimental values of percentage improvement in Surface Roughness attained through the confirmation experiments were within $95 \%$ of confidence intervals of respective response characteristic. 
Table-8: Outcome of Confirmation Experiments within Confidence Intervals

\begin{tabular}{|c|c|c|c|c|}
\hline $\begin{array}{l}\text { Response } \\
\text { Parameter }\end{array}$ & $\begin{array}{l}\text { Optimal } \\
\text { Machining } \\
\text { Parameters }\end{array}$ & $\begin{array}{l}\text { Predicted } \\
\text { Optimum } \\
\text { Value }\end{array}$ & $95 \%$ Confidence Interval & $\begin{array}{l}\text { Authentic Value } \\
\text { (Avg. } \\
\text { Confirmation } \\
\text { Exp.) }\end{array}$ \\
\hline $\begin{array}{l}\text { \%age Improvement } \\
\text { in } R_{a}\end{array}$ & $\mathrm{~W}_{2} \mathrm{~V}_{3} \mathrm{G}_{3}$ & 79.48 & $\begin{array}{l}\mathrm{CI}_{\mathrm{CE}}: 78.344<\Delta \mathrm{R}_{\mathrm{a}}>80.626 \\
\mathrm{CI}_{\mathrm{POP}}: 78.722<\Delta \mathrm{R}_{\mathrm{a}}>80.238\end{array}$ & 79.243 \\
\hline
\end{tabular}

\section{CONCLUSION}

The important conclusions from the present experimental study are summarized below:

$>$ Effect of machining parameters i.e. work-piece material, voltage and inter-electrode gap (IEG) on percentage improvement in SR was prominent.

$>$ Work-piece material was established as most significant factor affecting percentage improvement in SR followed by Inter-electrode gap and Voltage.

$>$ Highest value of Percentage Improvement was observed in case of brass as work-piece and lowest in case of mild steel.

$>$ Percentage Improvement in $\mathrm{R}_{\mathrm{a}}$ was increased linearly in case of IEG. Highest Percentage Improvement in $\mathrm{R}_{\mathrm{a}}$ was observed at $0.6 \mathrm{~mm}$ and lowest was observed at $0.2 \mathrm{~mm}$.

$>$ Percentage improvement in $\mathrm{R}_{\mathrm{a}}$ was increased gradually as voltage was change from $10 \mathrm{~V}$ to $18 \mathrm{~V}$. Percentage Improvement in $\mathrm{R}_{\mathrm{a}}$ was highest at $18 \mathrm{~V}$ and lowest at $10 \mathrm{~V}$.

$>$ The optimal set of parameters were second level of work material (Brass), third level of voltage (18V) and third level of IEG $(0.6 \mathrm{~mm})$.

$>$ Overall, it was found that characteristics of work material influence the Improvement in Surface Roughness as well as other operating conditions of ECM process.

\section{ACKNOWLEDGEMENTS}

The authors appreciatively acknowledge the Technical Education Quality Improvement Programme (TEQIP) scheme of World Bank for funding electrochemical machining apparatus used for experiments at Mechanical Engineering Department of Govt. College of Engineering, Salem, Tamilnadu, India.

\section{REFERENCES}

[1]. Neto, J., Silva, E., and Silva, M., (2006) "Intervening variables in electrochemical machining" Journal of Materials Processing Technology, Vol. 179, pp. 92-96.

[2]. Uttarwar, S., and Chopade, I., (2009) "Effect of voltage variation on MRR for stainless steel EN series 58A (AISI $302 b$ ) in electrochemical machining: a practical approach" Proceedings of the World Congress on Engineering, Vol. II, London, U.K.
[3]. A. Moarrefzadeh, (2011) "Finite-Element Simulation of dimensional limitation of Electro Chemical Machining (ECM) Process" International journal of multidisciplinary sciences and engineering, Vol. 2, NO. 7, pp. 101-107.

[4]. Chakradhar, D., and Gopal, A., (2011) "Multi-Objective Optimization of Electrochemical machining of EN31 steel by Grey Relational Analysis" International Journal of Modeling and Optimization, Vol. 1, No. 2, pp. 113 - 117.

[5]. Ganesan, G., Senthilkumar, C., and Karthikeyan, R.., (2011) "Parametric optimization of electrochemical machining of $\mathrm{Al} / 15 \% \mathrm{SiCp}$ composites using NSGA-II" Transaction of nonferrous metal society of China, Vol. 21, pp. 2294-2300.

[6]. Acharya, B., Mohanty, C., and Mahapatra, S., (2013) "Multi-objective optimization of electrochemical machining of hardened steel using NSGA II" Procedia Engineering, Vol. 51, pp. 554-560.

[7]. Bisht, B., Vimal, J., and Chaturvedi, V., (2013) "Parametric Optimization of Electrochemical Machining Using Signal-To-Noise (S/N) Ratio" International Journal of Modern Engineering Research, Vol. 3, Issue.4, pp. 19992006.

[8]. Goswami, R., Chouhan, R., and Chaturvedi, V., (2013) "The implementation of taguchi approach on ECM process parameters for mild steel and aluminium" International Journal of Research in Engineering \& Applied Sciences, Vol. 3, pp. $53-62$.

[9]. Das, M., Kumar, K., Barman, T., and Sahoo, P., (2014) "Investigation on Electrochemical Machining of EN31 Steel for Optimization of MRR and Surface Roughness using Artificial Bee Colony Algorithm" Procedia Engineering, Vol. 971, pp. 1587 - 1596.

[10]. Habib, S., (2014) "Experimental Investigation of Electrochemical Machining Process using Taguchi Approach" International Journal of Scientific Research in Chemical Engineering, Vol. 1(6), pp. 93-105.

[11]. Sathiyamoorthy, V., and Sekar, T., (2014) "Experimental studies on improving the performance of electrochemical machining of high carbon, high chromium die steel using jet patterns" Carbon - Science and Technology, Vol. 6, pp. $321-329$.

[12]. Rao, S., and Padmanabhan, G., (2015) "Parametric optimization in electrochemical machining using utility based taguchi method" Journal of Engineering Science and Technology, Vol. 10, No. 1, pp. 81 - 96. 


\section{BIOGRAPHIES}

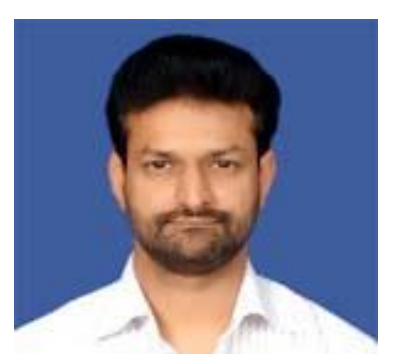

Ramandeep Singh I received my B.tech degree from Regional Engineering College, Jalandhar, Punjab, India, in 1998, the M.tech degree from Regional Engineering College, Kurukshetra, India, in 2000 and is pursuing my doctorate studies from PEC University of Technology, Chandigarh, India. I am having more than fourteen years of experience in industry and teaching of graduate and postgraduate students. I am having more than 30 research papers to my credit. Also guided three postgraduate students.

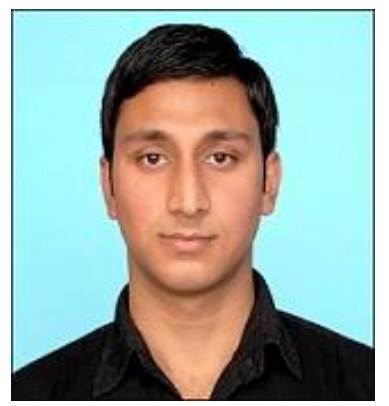

Nikhil Gandotra received his degree of B.tech in Mechanical Engineering from DAVInstitute of Engineering and Technology, Jalandhar, Punjab, India in June 2012. He is pursuing M.tech in Mechanical Engineering with specialization in Production from DAV University, Jalandhar, Punjab, India.He is having one yearexperience in teaching of diploma students. His areas of interest include Non-conventional machining, Production\& Industrial engineering, Virtual manufacturing, Quality control and improvement. 